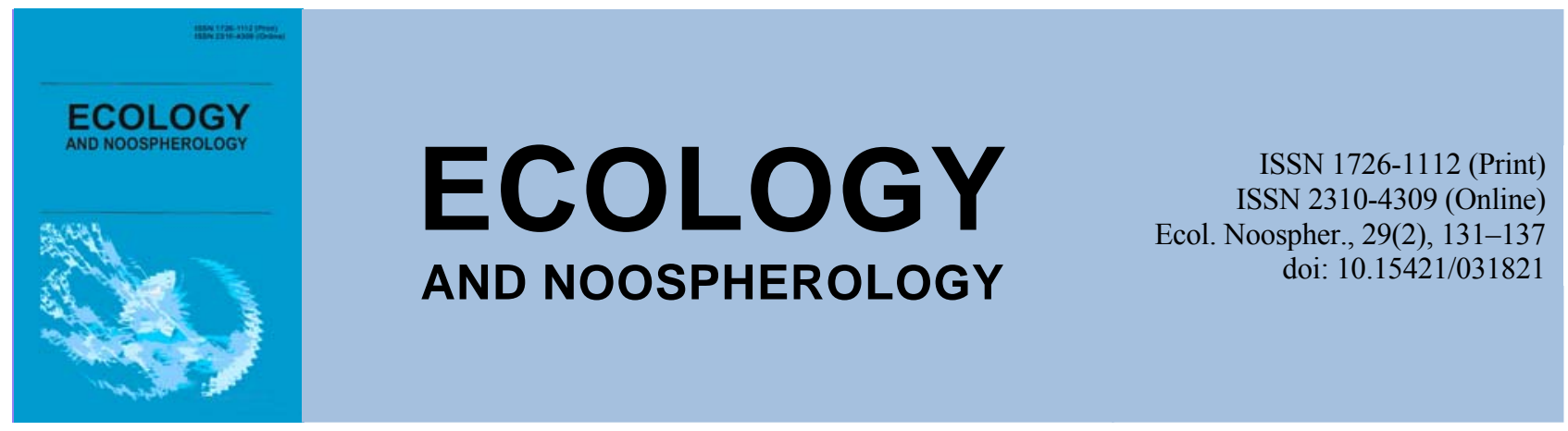

\title{
Effect of zoogenic litter on soil's chemical properties in forest biogeocoenoses of steppe Prydniprovia
}

\author{
M. V. Shulman, O. Y. Pakhomov \\ Oles Honchar Dnipro National University, Dnipro, Ukraine
}

Article info

Received 11.11.2018

Received in revised form

16.11.2018

Accepted 20.11.2018

Oles Honchar Dnipro

National University,

Gagarin Ave., 72, Dnipro,

49010, Ukraine.

Tel.: +38-099-772-43-49

E-mail:marishu@ukr.net

\begin{abstract}
Shulman, M. V., \& Pakhomov, O. Y. (2018). Effect of zoogenic litter on soil's chemical properties in forest biogeocoenoses of steppe Prydniprovia. Ecology and Noospherology, 29(2), 131-137. doi:10.15421/031821
\end{abstract}

The aspects of the process of decomposition and recycling of zoogenic litter (dead animals of different classes) were first ascertained for the steppe Prydniprovia. Influence of destruction of necrotic organic matter on soil properties ( $p H, N P K$-complex) in forest ecosystems in the steppe zone of Ukraine was estimated. Decomposition and recycling processes of dead animals (chickens, rats) on the experimental plots in biogeocoenoses with artificial oak plantations, sampling soil under dead bodies after the active stages of decomposition with different soil horizons at the same time with control samples, its chemical analysis allowed to determine the effect of degradation necrotic organic matter on the $p H$ value and the content of some chemical elements $(N, P, K)$ in the soil studied ecosystems. In this article the results of investigation of the effect of zoogenic litter on some chemical properties of soil in forest biogeocoenoses of steppe Prydniprovia are presented. The effect of chickens and rats corpses' decomposition on the $\mathrm{pH}$ of soil, nitrogen, phosphorus and potassium indexes in the soil is analyzed. The influence of the expansion of animal carcasses on soil chemical properties in different soil horizons compared with control values (without the presence of animal carcasses) is identified. It was found that under the effect of decomposition of animals' corpses the $p H$ of the soil increases. Under the corpses of chickens $p H$ increases by $6,4-16,7 \%$, and rats $-2,2-$ $14,2 \%$ compared to control values. The content of nitrogen in the soil under the corpses of chickens increases by $9,5-42,2 \%$, and under the corpses of rats - to $25,5-25,7 \%$. Phosphorus content under the corpses of chickens increases by $28,4-107,7 \%$ of rats - to $57,5-75,7 \%$. The content of potassium in the soil under the corpses of chickens increased by $3,63 \%$ to $69,8 \%$, and the corpses of rats - by $6,8-23,0 \%$. Consequently zoogenic litter is an important factor in the accumulation of NPK-complex in the soil. Thus process of animal corpse decomposition has positive effect for chemical properties of forest soil and biogeocoenoses generally.

Keywords: zoogenic litter; necrotic organic matter; corpses of chickens; corpses of rats; excrements; NPK-complex in the soil; soil horizons

\section{Вплив зоогенного опаду на хімічні властивості грунту в лісових біогеоценозах степового Придніпров'я}

\author{
М. В. Шульман, О. Є. Пахомов
}

Дніпровський національний університет імені Олеся Гончара, Дніпро, Україна

У статті представлено результати досліджень впливу зоогенного опаду на деякі хімічні властивості грунту в лісових біогеоценозах степового Придніпров'я. Досліджено вплив розкладання трупів курчат і щурів на: рівень $p H$ грунту, вміст азоту, фосфору та калію в грунті. Проаналізовано вплив розкладання трупів тварин на хімічні властивості грунту на різних грунтових горизонтах, порівняно 3 контрольними значеннями (без наявності трупів тварин). 3'ясовано, що за дії розкладання трупів тварин рівень $p H$ грунту підвищується. Під трупами курчат $p H$ зростає на $6,4-16,7 \%$, а щурів - на $2,2-$ $14,2 \%$ відносно контрольних значень. Вміст азоту в грунті під трупами курчат зростає на 9,5-42,2 \%, а під трупами щурів на 25,5-25,7 \%. Вміст фосфору під трупами курчат зростає на 28,4-107,7 \%, щурів - на 57,5-75,7 \%. Вміст калію в грунті під 
трупами курчат підвищується на 3,63 \% до 69,8 \%, а під трупами щурів - на 6,8-23,0 \%. Отже, зоогенний опад - важливий фактор у накопиченні $N P K$-комплексу в грунті.

Ключові слова: зоогенний опад; некроорганіка; трупи курчат; трупи щурів; екскременти; $N P K$-комплекс у грунті; грунтові горизонти

\section{Вступ}

Грунт - найважливіший і невід’ємний компонент будьякого біогеоценозу. Саме в ньому відбувається взаємодія живої та неживої природи, тому він належить до класу біокосних тіл. Хімічні елементи мінеральної природи, звільняючись із кристалічних граток мінералів, стають частиною живої речовини, беруть участь у ії життєвих процесах. I навпаки, жива речовина, відмираючи, мінералізується, переходить у мінеральну форму. У результаті життєдіяльності тваринного населення у вигляді зоогенного опаду до екосистем потрапляє значна частина переробленої автотрофної i гетеротрофної біологічної продукції. Зоогенний опад представлений відмерлою частиною зооценозу (трупи тварин) i трофометаболічним поверненням у вигляді екскреторних виділень (Pakhomov, 1998 b; Domnich, 2014).

Відмирання чи загибель тварин постійно відбувається у природі, їх трупи стають ресурсом для мікроорганізмів, безхребетних-некрофагів чи хребетних-сміттярів, тваринсанітарів. У наземних екосистемах серед усього комплексу деструкторів некроорганіки основну частину тканин утилізують комахи, а саме двокрилі та твердокрилі. Завдяки злагодженій діяльності некробіонтів та некрофагів відбувається прискорення розкладання трупів тварин. Представники некроентомофауни також беруть участь у процесі мінералізації через розкладання складних гнильних речовин до найпростіших компонентів, роблять ïx доступними для інших організмів.

Вплив зоогенного опаду (трофометаболіти й трупи тварин) на хімічні властивості грунту має два прояви. Перший - це додаткове надходження цінного добрива, де в результаті деструкції зоогенного опаду грунт збагачується неорганічними та мінеральними речовинами. Другий екскременти й трупи тварин стають хімічним каталізатором, що прискорює деструкційний процес накопиченого запасу органічної речовини. Обидва ці прояви зумовлюють зміни хімічних властивостей грунтів i підвищують їх родючість (Bulakhov et al., 1989; Pakhomov, 1998 a).

Природна смертність мікромамалій, зокрема мишоподібних гризунів, у природних екосистемах у середньому становить: при високій чисельності популяцій (до 600 особ./га) - 90-95\%; при середній чисельності (350-400 особ./га) - 75-85\%; при низькій чисельності (200-350 особ./га) - 60-70 \% (Bulakhov, Pakhomov, 2006).

Причинами природної загибелі мікромамалій можуть бути: інфекційні захворювання i епізоотії, природна смерть, їх участь у трофічних ланцюгах як їжа макроконсументів вищих порядків (Bulakhov, Pakhomov, 2006; Kucheruk, 2006). Слід зазначити, що загибель може наступити як на поверхні грунту, так і в нірках, що має велике значення у швидкості розкладання трупів тварин, оскільки обмеження доступу комах некрофільного комплексу до трупу сповільнює процес розкладання в 1,53 рази, у порівнянні з інтенсивністю розкладання трупів при вільному доступі некроентомофауни (Payne, 1965).

Причини природної загибелі птахів (для осілих i кочуючих видів) у природних екосистемах можливі такі: дефіцит корму, природна смертність, як ланка в трофічних ланцюгах екосистеми, інфекційні хвороби та епізоотії, сувора зима (Bulakhov et al., 2008).

Трупи стають ресурсом для мікроорганізмів, безхребетних-некрофагів або хребетних-сміттярів тварин-санітарів. У наземних екосистемах серед всього комплексу деструкторів некроорганіки основну частину тканин утилізують комахи, головним чином представники рядів Diptera и Coleoptera (Payne, 1965; Ozerov, 1989; Blackith \& Blackith, 1990; Tantawi, El-Kady, Greenberg et al., 1996; Goff, 2000; Lyabzina, 2003). Завдяки злагодженій діяльності некробіонтів i некрофагів відбувається інтенсифікація розкладання та утилізації трупів тварин (Early \& Goff, 1986; Dillon, 1997; Lyabzina, 2003).

Некроентомофауна також бере участь у процесах мінералізації i в загальному біогеоценологічному колообігу речовин через розкладання (Payne, 1965; Early \& Goff, 1986; Dillon, 1997).

Визначення впливу процесів розкладання зоогенного опаду на грунти різних за типом біогеоценозів, вивчення некрофільної фауни, участі іiі в процесі розкладання некроорганіки в природі, а також в умовах підвищеного антропогенного тиску є важливими аспектами екології.

\section{Матеріали та методи досліджень}

Для визначення впливу деструкції зоогенного опаду на значення $p H$ та вміст деяких хімічних елементів $(N, P, K)$ грунту нами був проведений експеримент з розкладання та утилізації трупів тварин (курчата, щури) на експериментальній ділянці в біогеоценозі зі штучним дубовим насадженням (ПД № 224, с. Андріївка, Новомосковський $\mathrm{p}-\mathrm{H}$, Дніпропетровська обл.). Проби грунту відбиралися у шестиразовому повторенні 3 кожного грунтового горизонту $(H o-0-10 \mathrm{~cm} ; H 1-10-20 \mathrm{~cm} ; H 2-$ 20-30 см) як під трупами курчат, так і під трупами щурів після активних стадій розкладання зоогенного опаду (8-10-й день). Контрольні зразки - проби грунту 3 кожного грунтового горизонту без трупів. Для хімічного аналізу проб грунту застосовували методи колориметрії (визначення рухомої форми фосфатів у витяжці за Чириковим та нітратного азоту 3 використанням хромотропової кислоти), полум'яної фотометрії (визначення рухомої форми калію у витяжці за Чириковим). Значення $p H$ водної витяжки зразків грунту визначали за допомогою $p H$-метра (Pakhomov et al., 2010).

\section{Результати та їх обговорення}

Вплив зоогенного опаду на рН трунту. У цілому вплив процесів розкладання зоогенного опаду позитивний. Наприклад, за даними А. В. Домніча (2015), екскреції ратичних в умовах острівних екосистем чинять інтегрований опосередкований і безпосередній вплив на грунт, що сприяе процесу гумусоутворення у верхніх шарах грунту. Кількість гумусу, залежно від типу екосистем і виду ратичних, збільшується в 1,5-3,7 разу. Гідролітична кислотність знижується на 29-38\%. Ефективність впливу екскрецій на збільшення у грунті поживних речовин (комплекс $N P K$ ) залежить від ступеня родючості грунтів. У збіднених грунтах він більш істотний, ніж у родючих - лісових екосистемах (Domnich, 2015). А за даними K. Cobaugh et al. (2015), у результаті досліджень впливу розкладання трупів людей на функціональну й структурну сукцесії грунтових мікробіальних угруповань виявлено, що розкладання некроорганіки викликало імпульси зростання вуглецю, поживних речовин (зокрема, аміаку), підвищення мікробіальної активності в грунті (Cobaugh, Schaeffer et al., 2015).

Розкладання та утилізація трупів тварин (курчат, щурів) на експериментальній ділянці у біогеоценозі зі штучним дубовим насадженням (ПД № 224, с. Андріївка, Новомосковський р-н, Дніпропетровська обл.), відбір проб 
грунту під трупами після активних стадій розкладання 3 різних грунтових горизонтів одночасно 3 контролем на хімічний аналіз дозволив визначити вплив деструкції некроорганіки на значення $p H$ та вміст деяких хімічних елементів $(N, P, K)$ грунту в досліджених біогеоценозах.

За результатами наших досліджень процес розкладання та утилізації трупів тварин чинить позитивну дію на зниження кислотності грунту (рис. 1). У контрольних вимірах $p H$ грунту відмічається поступове підвищення індексу 3 поверхневих шарів до глибини $30 \mathrm{cm:} \mathrm{у}$ поверхневому грунтовому горизонті (Ho) значення $p H$ складало у середньому 6,88, на $H 1$ грунтовому горизонті (гг) на 3,2\% вище, а на $H 2$ гг на 8,3\% вище відносно контролю у Но гг. Під трупами курчат показники $p H$ проб грунту 3 усіх грунтових горизонтів мали вище значення відносно контрольних зразків, але порівняно 3 контрольними індексами у Но горизонті під трупами реакція зростає в середньому на $16,7 \%$, у $H 1$ гг - на 8,4 \% щодо контрольного індексу $p H$ у цьому горизонті та на $6,4 \%$ вище за контроль у $H 2$ гг. Отже, найвищий показник $p H$ розкладання трупів курчат реєструється на $H$ грунтовому горизонті.
За впливу розкладання трупів щурів також спостерігається підвищення реакції грунту порівняно 3 контрольними зразками: у $Н о$ гг - на 2,2 \% та у $H 2$ г - на 14,2 \% відносно контрольних значень у наведених грунтових горизонтах. На $H 1$ п показник реакції грунту, навпаки, зменшується в середньому на 10,6\% щодо індексів контролю в цьому шарі грунту. Таким чином, максимальне значення $p H$ грунту $(8,51)$ відмічається під трупами щурів у горизонті 20-30 см (рис. 1). Вірогідно, це пов'язано з більш тривалим процесом розкладання трупів щурів порівняно 3 трупами птахів, 3 наявністю більшої кількості некроорганіки i, як наслідок, більшим виділенням ексудату в грунт. Імовірно, рідкі продукти розкладання некроорганіки щурів швидко всмоктуються в шари грунту й акумулюються в більш глибинних грунтових горизонтах 3 більш щільною механічною структурою. Зазначимо, що підвищення рівня $p H$ грунту може зумовлюватися й змінами грунтового мікробоценозу, оскільки під трупами, що розкладаються, підвищується вміст протеобактерій, а ацидобактерії зменшують свою чисельність. У цілому після стадій активного розкладання некроорганіки темпи зростання біомаси мікроорганізмів в глибинних шарах грунту скорочуються (Cobaugh, Schaeffer et al., 2015).

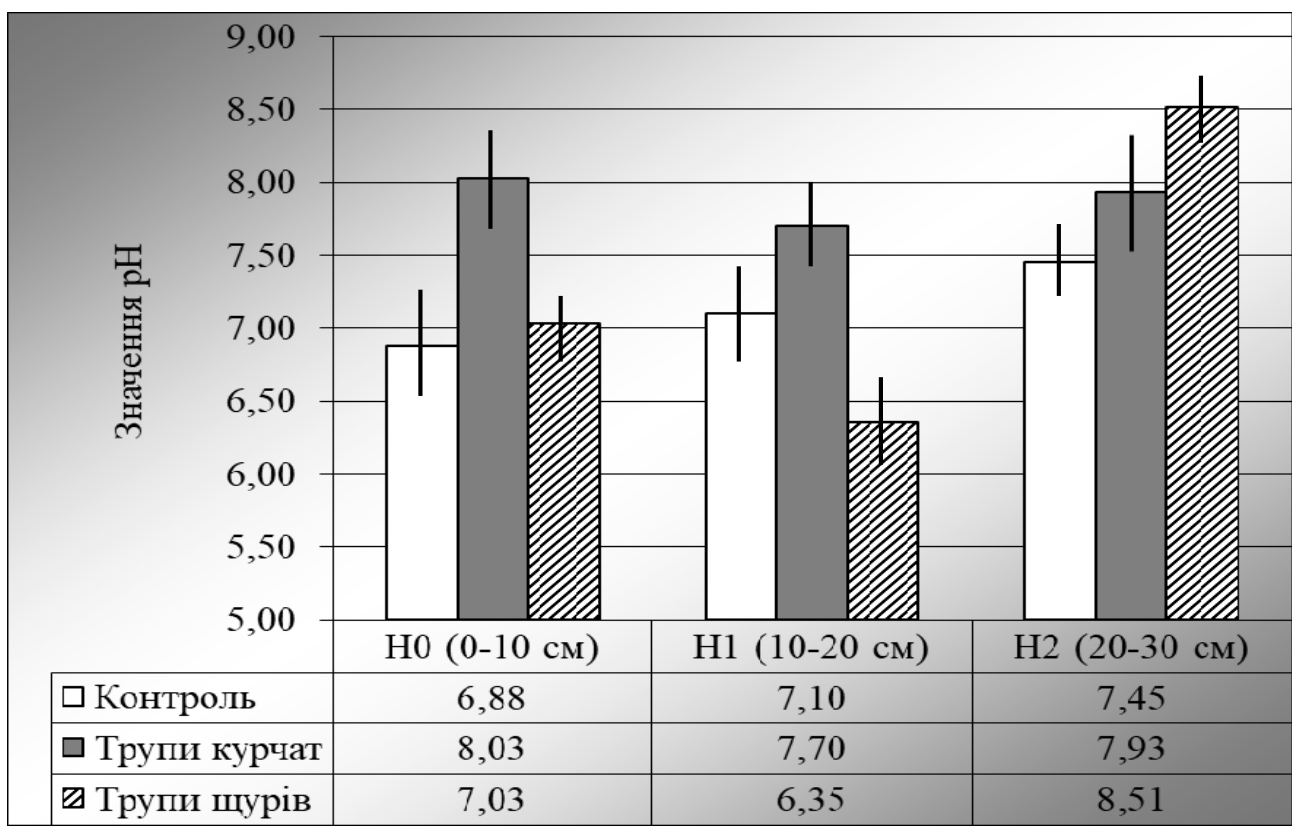

Рис. 1. Вплив зоогенного опаду на рН водної витяжки грунту

Умовні позначення: стовпці - середнє значення ознаки, вертикальні лінії - стандартна похибка

Слід зауважити, що зоогенний опад відіграє суттєву роль у прискоренні деструкційного процесу під час розкладання підстилки. Під трупами тварин, що розкладаються, на 3-5-й день експозиції трупів (активна фаза розкладання) підстилка сильно дефрагментується завдяки інтенсивній діяльності комах некробіонтного комплексу, особливо через виділення протеолітичних ферментів у процесі життєдіяльності личинок некробіонтних двокрилих (Calliphoridae, Sarcophagidae, Muscidae). Завдяки некробіонтним Coleoptera (представникам Necrophorinae та Geotrupidae) відбувається перемішування фрагментів підстилки i верхнього шару грунту. Це сприяє й поліпшенню фізичних властивостей грунту - зменшенню його щільності, підвищенню порозності та водопроникності (Pakhomov, 1998 b; Pakhomov et al., 2010). За даними J. Carry (1994), діяльність личинок жуків-копрофагів та некрофагів сприяє прискоренню гуміфікації та мінералізації речовин підстилки, перетворенню їх на грунтовий детрит i перемішуванню з мінеральною масою грунту (Carry, 1994).

Надходження і накопичення комплексу $N P K$ у грунті за дії зоогенного опаду зумовлене багатьма факторами: кількістю трупної маси тварини, типом зовнішніх покривів трупа (луска, хутро, пір'я тощо), типом біогеоценозу, де міститься труп тварини, тривалістю експозиції трупа та кліматичними факторами - особливо дією посушливого періоду, який знижує i навіть призупиняє деструктивні процеси зоогенного опаду (Ozerov, 1988; Pakhomov, 1998 b).

Вилив зоогенного опаду на вміст азоту в грунті. Поживні елементи в грунті перебувають у розчиненому або обмінному стані у вигляді йонів. Рослини 3 грунту крім води одержують різні мінеральні речовини: нітроген (амонійний та нітратний іони), фосфор (моно- й дифосфати), калій, кальцій, магній, сульфур, ферум, манган, купрум, молібден, бор, цинк тощо. Такі хімічні елементи, як $N$, $P, \quad K, \quad$ відіграють виняткову роль у розвитку органічного світу. Особливо важливе місце тут посідає азот як один 3 елементів-органогенів. Через те що він фактично міститься в атмосфері, рослини відчувають потребу в ньому, оскільки використовувати для своїх потреб вони можуть лише нітроген грунтових ресурсів (Pakhomov et al., 2010; Cobaugh et al., 2015). 
Дослідження впливу зоогенного опаду на вміст азоту в грунті виявило зростання кількості азоту в усіх експериментальних зразках грунту порівняно 3 контролем (рис. 2). Причому контрольні значення вмісту нітрогену поступово знижуються від поверхневих грунтових горизонтів до глибинних, а саме: $H о$ (на $30,0 \%$ ) > HI (на $55,5 \%)>H 2$. Отже, середній вміст азоту в контрольних зразках грунту на глибині 20-30 см виявився мінімальним (0,28 мг/100 г грунту). Аналогічна тенденція спостерігається в пробах грунту під трупами курчат: $Н$ о (на 46,1\%) > H1 (на $43,5 \%)>H 2$. У зразках грунту під трупами щурів показники вмісту азоту виявились практично однаковими. Найвищий середній показник вмісту азоту зареєстрований на $H 1$ гг (1,18 мг/100 г грунту), що на $87,3 \%$ вище за аналогічний показник у контролі.

Узагалі простежується тенденція зниження кількості азоту в грунті з поверхневих шарів до глибоких, як це показано на діаграмі з контрольними зразками грунту та під трупами курчат.

Високі показники вмісту азоту на Но грунтовому горизонті зареєстровані під трупами курчат (на 42,2 \% вище контрольного індексу). На $H 2$ грунтовому горизонті (20-30 см) відмічається збільшення показників вмісту азоту на $39,3 \%$ і на $257 \%$ під трупами курчат і щурів відповідно. Проби грунту на хімічний аналіз відбиралися одночасно під усіма типами трупів. Отже, вміст азоту накопичується більше в поверхневих та глибинних шарах грунту (останнє реєструється у випадку з трупами щурів).

Слід зауважити, що порівняно 3 розкладанням екскрементів хребетних тварин (за літературними даними) відмічається схожа тенденція (Bulakhov, Dubina, Reva, 1989; Pakhomov, 1998 a, 1998 b; Bulakhov, Pakhomov, 2000 a, 2000 b). Наприклад, за даними О. Є. Пахомова (1998), під екскреціями лисиці у загальній 50-сантиметровій товщі грунту вміст азоту практично однаковий 3 контролем, де його зниження становить до $6 \%$. У верхніх шарах грунту (0-10 см) його значно менше порівняно 3 глибиною 10 20 см, де кількість азоту збільшується і перевищує контрольні індекси на $400 \%$ (Pakhomov, 1998 b). А за матеріалами досліджень А.В. Домніча, під екскреціями козулі європейської за півроку експозиції вміст азоту в грунті збільшується в середньому на 38,3 \% (Domnich, 2014).

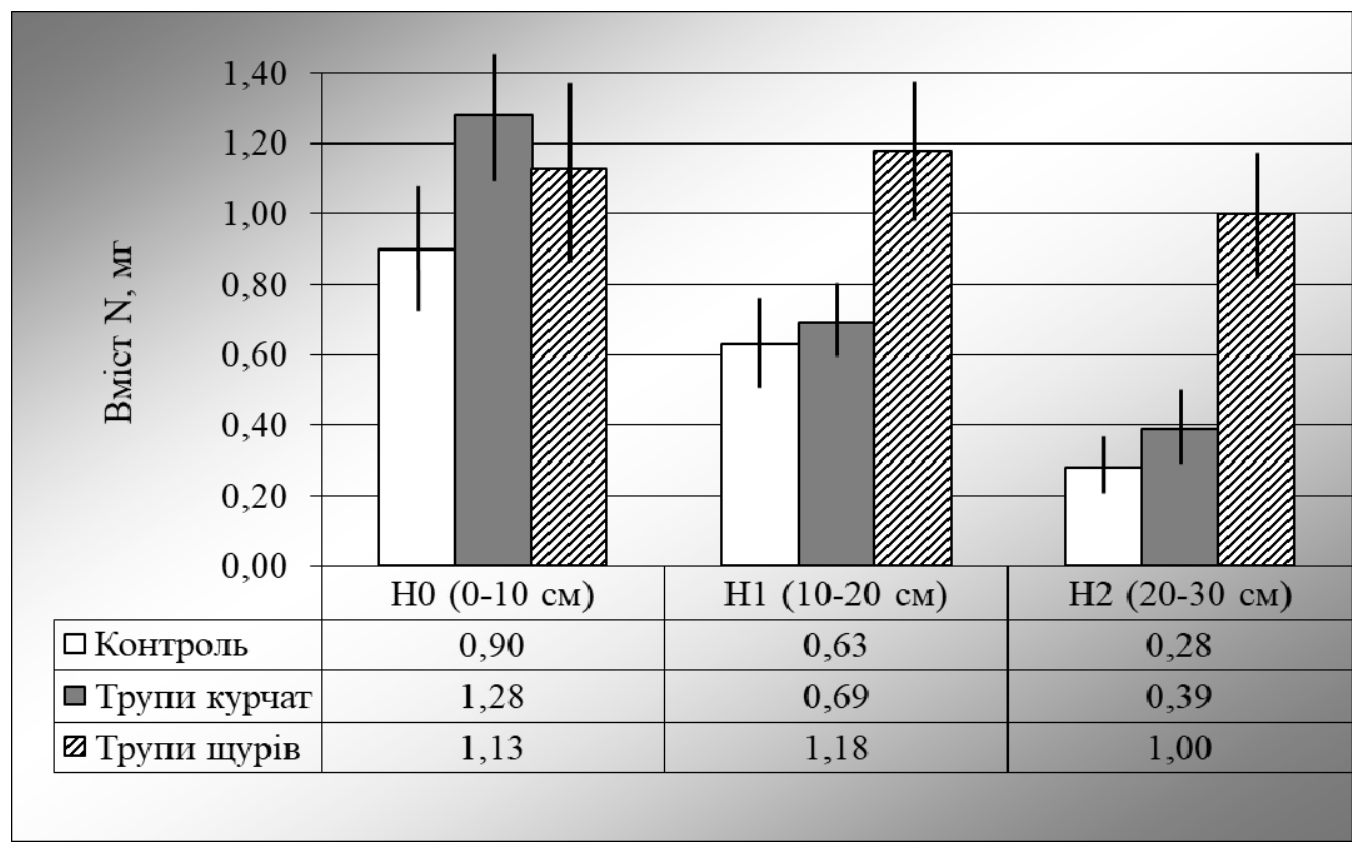

Рис. 2. Вплив зоогенного опаду на вміст азоту в грунті, мг/100 г грунту

Умовні позначення показано на рис. 1.

Таким чином, максимальне значення азоту відмічається у зразках грунту під трупами курчат у верхньому грунтовому горизонті (1,28 мг/100 г грунту). У середньому на $9,2 \%$ нижчим виявився показник дослідженого індексу у зразку грунту під трупами щурів у H1 грунтовому горизонті. Зазначимо, що ефективність розкладання трупів щурів порівняно 3 розкладанням курчат виявилась вищою - реєструються високі показники вмісту нітрогену в пробах грунту на всіх горизонтах. Це, імовірно, пояснюється тим, що азот у результаті розкладання м'яких трупних тканин активно звільняється завдяки деструкційним процесам за участю мікроорганізмів, проникає у більш глибокі шари грунту, де здатен накопичуватися. Трупи птахів розкладаються практично вдвічі швидше, ніж трупи ссавців, і виділяється значно менше ексудату, який не проникає у більш глибинні шари грунту.

Зазначимо, що під час розкладання некроорганіки спостерігається збільшення різновидностей азоту пептидів, амінокислот, амонійних сполук. Виявлено підвищену активність протеази і вільних коефіцієнтів обертання амінокислот, що сприяє збільшенню швидкості дихання мікробоценозу під трупами, підвищенню інтенсивності мінералізації азоту та вуглецю (Cobaugh et al., 2015). Додаткове надходження азоту до грунтів сприяє продуктивності рослинних угруповань і біогеоценозів у цілому (Stantso, Chernenko, 1983; Pakhomov et al., 2010).

Вилив зоогенного опаду на накопичення фосфору в трунті. Фосфор у грунт повертається із зоогенним опадом (екскрементами і під час гниття трупів). Фосфоробактерії переводять органічний фосфор в неорганічні сполуки. В організмі фосфор акумулюється переважно у скелеті, м'язах і нервовій тканині (Stantso, Chernenko, 1983).

Дослідження впливу зоогенного опаду на накопичення фосфору в грунті виявили максимальний рівень вмісту фосфору також під трупами курчат на Но грунтовому горизонті. Під трупами щурів на Но і $H 2$ горизонтах рівень фосфору майже однаковий (рис. 3).

У цілому простежується тенденція акумуляції фосфору у верхньому грунтовому горизонті $(0-10 \mathrm{~cm})$ та на глибині 20-30 см, особливо це помітно у зразках грунту під трупами щурів (H2 ГГ), де середній показник вмісту фосфору виявився на 75,6 \% вищим за контрольний індекс i на $28,4 \%$ вищим за аналогічний показник розкладання трупів курчат. Слід зауважити, що порівняно 3 розкладанням екскрементів хребетних тварин (за 


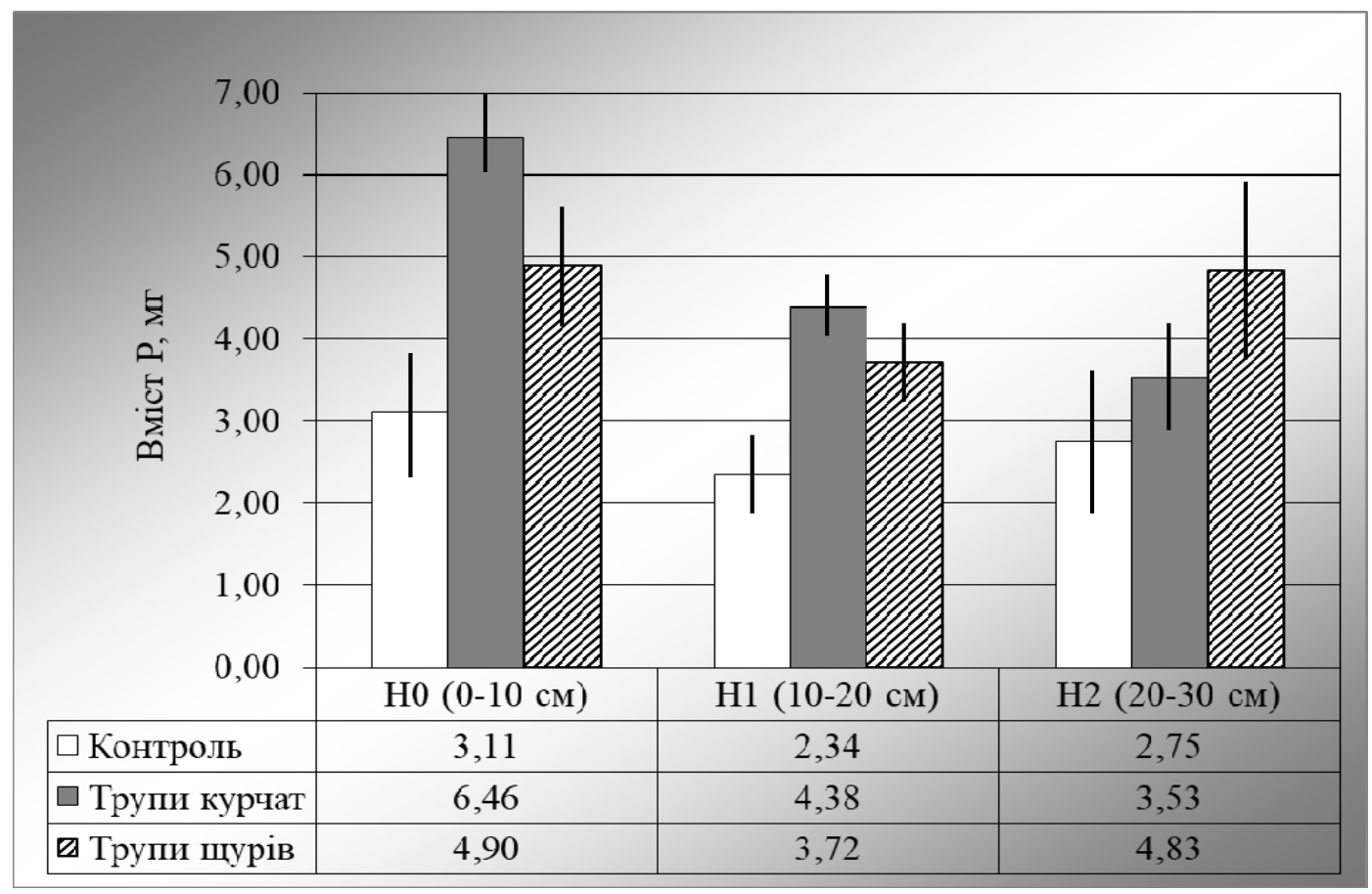

Рис. 3. Вплив зоогенного опаду на вміст фосфору в грунті, мг/100 г грунту Умовні позначення показано на рис. 1.

літературними даними) відмічається схожа тенденція. Наприклад, за даними О. Є. Пахомова, вплив екскрецій кабана, козулі та лисиці на накопичення фосфору в грунтах штучних дубняків виявился позитивним. Так, у 50сантиметровій товщі грунту під екскреціями козулі його вміст збільшується на 84,9 \%, під екскреціями кабана та лисиці - в середньому на $39,2 \%$. У верхніх горизонтах вміст фосфору завжди більший порівняно з контролем (Pakhomov, 1998 b). А за результатами досліджень А. В. Домніча, за впливу екскрементів копитних відбувається поступове зростання запасів фосфору у середньому на 60-70 \%; вміст фосфору у грунтах за впливу екскрецій ратичних збільшується на 14 $193 \%$ (Domnich, 2014, 2015). Цікаво, що, за даними K. Cobaugh et al. (2015), у пробах грунту, зібраних під трупами людей після активних фаз їх розкладання, спостерігається підвищення активності фосфодіестерази та ліполітична активність (Cobaugh et al., 2015).

У наших дослідженнях максимальне значення фосфору виявлене на Но грунтовому горизонті під трупами курчат (6,46 мг/100 г грунту), це вище на $107,7 \%$ відносно контрольного показника. Зазначимо, що під трупами курчат вміст фосфору поступово знижується у напрямку 3 верхніх шарів грунту до глибинних: $Н$ (на 47,5\%) > H1 (на $24,1 \%$ ) $>H 2$. А в контрольних зразках та в пробах грунту під трупами щурів відмічається схожа тенденція - у Но та $H 2$ гГ показники вмісту фосфору вищі за аналогічні у $H 1$ гГ (рис. 3).

Вилив зоогенного опаду на накопичення калію в tрунті. Відомо, що частина йонів калію за дисоціювання молекул $\mathrm{K}_{2} \mathrm{CO}_{3}$ залишається в грунтовому розчині, який для рослин слугує джерелом живлення. Але більша частина йонів калію поглинається колоїдними частинками грунту в малодоступній для коренів рослин формі. «Грунт поглинає калій, і в цьому його чудодійна сила», - вислів академіка О. Є. Ферсмана. Калій - життєво необхідний елемент для росту й розвитку рослин. Дефіцит його в грунті неодмінно спричинює в'янення і загибель рослинного організму. Для організму тварин калій також украй важливий біогенний метал. Солі калію не можуть бути замінені ніякими іншими солями. Вони містяться в крові, протоплазмі клітин, печінці й селезінці. У м'язах людини калій переважає над натрієм. Особливо багато калію міститься в мозку, печінці, серці та нирках людини (Stantso, Chernenko, 1983).
Наші дослідження впливу зоогенного опаду на формування калію в грунті експериментального біотопу виявили більш слабке вираження порівняно із загальною картиною накопичення азоту та фосфору. Подібна тенденція спостерігається в дослідженнях А. В. Домніча процеси зміни вмісту калію в грунті під екскреціями різних видів ратичних у різних умовах виявилися відносно сповільненими порівняно зі змінами в накопиченні азоту та фосфору (Domnich, 2015), але в середньому вміст калію в грунті під екскреціями копитних збільшується на $58 \%$ (Domnich, 2014). Під трупами щурів зростання середнього показника вмісту калію превалює над аналогічними показниками проб грунту під трупами курчат на $H$ о та $H 2$ грунтових горизонтах на $18,7 \%$ i $13,9 \%$ відповідно (рис. 4).

Вміст калію в поверхневому шарі грунту (0-10 см) під трупами щурів виявляється в середньому на $23 \%$ вищим порівняно 3 контролем. У $H 1$ гг домінує показник вмісту калію під трупами курчат, що на 24 \% вище за аналогічний показник у грунті під трупами щурів і на $69,8 \%$ вище за вміст калію в контрольних зразках грунту. У $\mathrm{H} 2$ грунтовому горизонті середні показники вмісту калію у всіх пробах майже однакові. Слід зазначити, що на цьому грунтовому горизонті за контрольний індекс вмісту калію вищим виявився тільки показник вмісту калію під трупами щурів (на 6,8 \%). Імовірно, незначне підвищення вмісту калію під трупами тварин зумовлене «моментальним» включенням цього елемента в кругообіг речовин у біотопі.

\section{Висновки}

1. За результатами наших досліджень показано, що процес розкладання та утилізації трупів тварин чинить позитивну дію на зниження кислотності грунту. Під трупами курчат показники $p H$ проб грунту з усіх грунтових горизонтів мали вищі значення відносно контрольних зразків: у Но грунтовому горизонті під трупами реакція зростає в середньому на $16,7 \%$, у $H 1$ гг - на $8,4 \%$ та на 6,4 \% вище за контроль у $H 2$ гг. Отже, найвищий показник $p H$ для розкладання трупів курчат реєструється на $H o$ грунтовому горизонті. За впливу розкладання трупів щурів також спостерігається підвищення реакції грунту порівняно з контрольними зразками: у Но гг - на 2,2 \% та в 


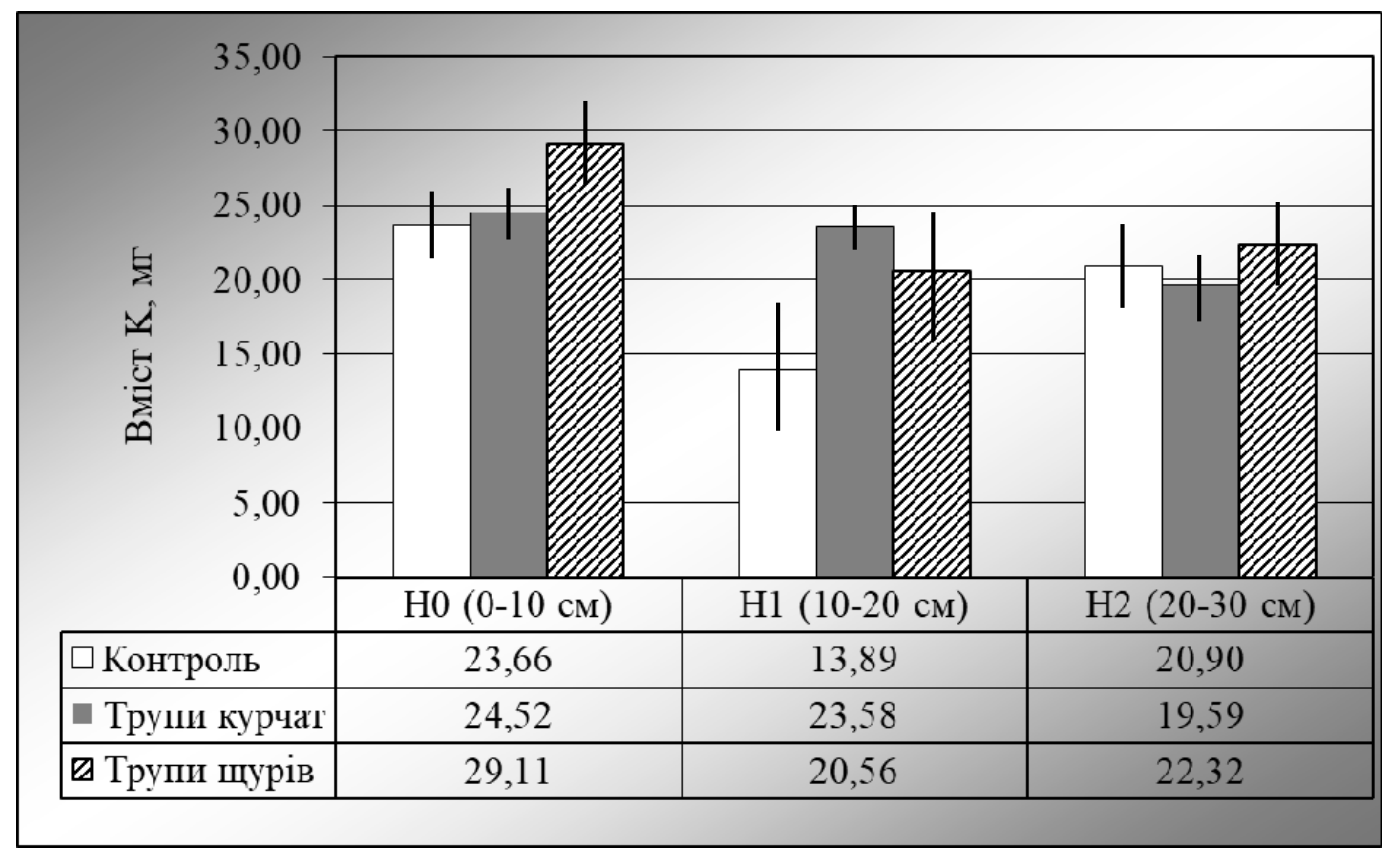

Рис. 4. Вплив зоогенного опаду на вміст калію в грунті, мг/100 г грунту

Умовні позначення показано на рис. 1.

$H 2$ гг - на 14,2 \% відносно контрольних значень у вказаних грунтових горизонтах. На $\mathrm{Hl}$ гг показник реакції грунту, навпаки, зменшується в середньому на $10,6 \%$ щодо індексів контролю в цьому шарі грунту. Таким чином, максимальне значення $p H$ грунту $(8,51)$ зареєстроване під трупами щурів у горизонті 20-30 см. Вірогідно, це пов'язано з більш тривалим процесом розкладання трупів щурів порівняно 3 трупами птахів, 3 наявністю більшої кількості некроорганіки i, як наслідок, більшим виділенням ексудату в грунт.

2. Дослідження впливу зоогенного опаду на вміст азоту в грунті виявило зростання кількості азоту в усіх експериментальних зразках грунту порівняно з контролем. Контрольні значення вмісту нітрогену поступово знижуються від поверхневих грунтових горизонтів до глибинних, а саме: $H o($ на $30,0 \%)>H 1$ (на 55,5\%) $>H 2$. Отже, середній вміст азоту в контрольних зразках грунту на глибині 20-30 см виявився мінімальним $(0,28$ мг/100 г грунту). Аналогічна тенденція спостерігається в пробах грунту під трупами курчат: $H о$ (на 46,1 \%) > H1 (на 43,5\%) > H2. У зразках грунту під трупами щурів показники вмісту азоту практично однакові. Найвищий середній показник вмісту азоту зареєстрований на $H 1$ гг (1,18 мг/100 г грунту), що на 87,3\% вище за аналогічний показник у контролі. Високі показники вмісту азоту на $Н$ о грунтовому горизонті зареєстровані під трупами курчат (на $42,2 \%$ вище контрольного індексу). На Н2 грунтовому горизонті $(20-30 \quad$ см $)$ відмічається збільшення цих показників на 39,3 \% і на 257 \% під трупами курчат і щурів відповідно. А максимальні цифри вказують на зразки грунту під трупами курчат у верхньому грунтовому горизонті (1,28 мг/100 г грунту).

3. Дослідження впливу зоогенного опаду на накопичення фосфору в грунті показали максимальне значення фосфору на Но грунтовому горизонті під трупами курчат (6,46 мг/100 г грунту); це вище на 107,7 \% відносно контрольного показника, але він поступово знижується 3 верхніх шарів грунту до глибинних: $Н о$ (на 47,5\%)> $H 1($ на $24,1 \%)>H 2$. А в контрольних зразках та в пробах грунту під трупами щурів відмічається схожа тенденція - у $H o$ та $H 2$ гГ показники вмісту фосфору вищі за аналогічні показники у $H 1$ гГ. У цілому простежується тенденція акумуляції фосфору у верхному грунтовому горизонті (0-
10 см) та на глибині 20-30 см, особливо це помітно у зразках грунту під трупами щурів (H2 IГ), де середній показник вмісту фосфору на 75,6 \% вищий за контрольний індекс і на $28,4 \%$ вищий за аналогічний показник щодо курчат.

4. За результатами досліджень впливу зоогенного опаду на формування калію в грунті експериментального біотопу виявлено: під трупами щурів зростання середнього показника вмісту калію превалює над аналогічними показниками проб грунту під трупами курчат на $H$ о та $H 2$ грунтових горизонтах на $18,7 \%$ і 13,9 \% відповідно. У $\mathrm{H2}$ грунтовому горизонті середні показники вмісту калію у всіх пробах майже однакові - вищим за контрольний індекс він виявився тільки в пробах грунту під трупами щурів (на 6,8\%). Таким чином, зоогенний опад - це загальний позитивний фактор у накопиченні азоту, фосфору та калію у грунті. Особливо значне накопичення цих елементів для більш глибоких горизонтів (20-30 см), оскільки збільшує їх доступність для коріння чагарників та деревостану, що сприяє формуванню фітоценозу.

5. 3'ясовано, що за дії розкладання трупів тварин рівень $p H$ грунту підвищується. Під трупами курчат $p H$ зростає на 6,4-16,7 \%, а щурів - на 2,2-14,2 \% відносно контрольних значень. Вміст азоту в грунті під трупами курчат зростає на 9,5-42,2 \%, а під трупами щурів - на $25,5-25,7 \%$. Вміст фосфору під трупами курчат зростає на $28,4-107,7 \%$, щурів - на 57,5-75,7\%. Вміст калію в грунті під трупами курчат підвищується на $3,63 \%$ до 69,8\%, а під трупами щурів - на 6,8-23,0 \%. Отже, зоогенний опад важливий фактор у накопиченні $N P K$-комплексу в грунті.

\section{References}

Blackith, R. E., Blackith, R. M. (1990). Insect infestations of small corpses. Journal of Natural History, 24, 699-709.

Bulakhov, V. L., Dubina, A. A., Reva, A. A. (1989). Vliyanie myishevidnyih gryizunov na intensivnost razlozheniya podstilki v poymennyih lesnyih biogeotsenozah Prisamarya [Effect of rodents on the intensity of decomposition of litter in the floodplain forest biogeocoenoses of Prysamar'ia]. Biogeotsenoticheskie issledovaniya lesov tehnogennyih landshaftov stepey Ukrainyi. Dnepropetrovsk. 162-167 (in Russian). 
Bulakhov, V. L., Gubkin, A. A., Ponomarenko, O. L., Pakhomov, O. Ye. (2008). Biolohichne riznomanittia Ukrainy. Dnipropetrovska oblast. Ptakhy (Aves: Non-Passeriformes) [Biological Diversity of Ukraine. The Dnipropetrovsk region. Birds (Aves: Non-Passeriformes)]. Dnipropetrovsk (in Ukrainian).

Bulakhov, V. L., Pakhomov, O. Ye. (2000 b). Seredovyshchetvirna funktsiia khrebetnykh yak ekolohichnyi mekhanizm tryvaloho zhyttia bioheotsenoziv [Environment forming function of vertebrate as ecological mechanism of biogeocoenoses longevity]. Problemy suchasnoi ekolohii. - Zaporizhzhia. 90 (in Ukrainian).

Bulakhov, V. L., Pakhomov, O. Ye. (2006). Biolohichne riznomanittia Ukrainy. Dnipropetrovska oblast. Ssavtsi (Mammalia) [Biological Diversity of Ukraine. The Dnipropetrovsk region. Mammals (Mammalia)]. Dnipropetrovsk (in Ukrainian).

Bulakhov, V. L., Pakhomov, A. E. (2000 a). Sredoobrazuyuschaya deyatelnost mlekopitayuschih kak bioticheskiy mehanizm v biotehnologicheskom protsesse obrazovaniya ekologicheskoy ustoychivosti pochv $\mathrm{v}$ usloviyah tehnogeneza [Environment forming activity of mammals as biotic mechanism in biotechnological process of ecological stability formation of soils in conditions of technogenesis]. Novoe $\mathrm{v}$ ekologii i zhiznedeyatelnosti. Dokl. Mezhdunar. ekol. kongressa. SPb.: BGTU. 2. 523-525 (in Russian).

Carry, J. (1994). Grassland invertebrates: ecology, influence on soil fertility and effects on plant growth. Chapman and Hall. London, UK. 340-345.

Cobaugh Kelly, L., Schaeffer Sean, M., De Bruyn Jennifer, M. (2015). Functional and Structural Succession of Soil Microbial Communities below Decomposing Human Cadavers.

Dillon, L. C. (1997). Insect succession on carrion in three biogeoclimatic zones of British Columbia. Burnaby, BC: Simon Fraser University. 37-42.

Domnich, A. V. (2014). Izmenenie chislennosti i sredoobrazuyuschaya deyatelnost dikih kopyitnyih na territorii zapovednika v period vosstanovleniya o. Hortitsa [Changes in the number and environment-forming activity of wild ungulates in the reserve during the period of recovery of the island Khortytsya]. Visnyk Kharkivckoho natsionalnoho universytetu im. V. N. Karazina. Seriia: biolohiia. 20(1100). 129-137 (in Russian).

Domnich, A. V. (2015). Ratychni yak strukturno-funktsionalnyi element ostrivnykh zapovidno-okhoronnykh terytorii pivdennoho skhodu Ukrainy [Ungulates as a structural and functional element of the island reserves and protected areas of southeast Ukraine]. Avtoref. dys. na zdobuttia nauk. stupenia kand. biol. nauk: spets. 03.00.16 - ekolohiia. Zaporizhzhia (in Ukrainian).

Early, M., Goff, M. L. (1986). Arthropod succession patterns in exposed carrion on the island of O'Ahu, Hawaiian Islands, USA. Journal of Medical Entomology, 23, 520-531.

Goff, M. L. (2000). A fly for the prosecution: how insect evidence helps solve crimes. Cambridge: Harvard University Press. 225 p.

Kucheruk, V. V. (2006). Izbrannyie trudyi [Selected works]. Moscow (in Russian).

Lyabzina, S. N. (2003). Bespozvonochnyie-nekrobiontyi i ih uchastie v utilizatsii organicheskogo veschestva $\mathrm{v}$ nazemnyih $\mathrm{i}$ vodnyih ekosistemah Evropeyskogo severa [Necrobiotic invertebrates and their participation in recycling organic matter in terrestrial and aquatic ecosystems of the European North]. Avtoref. dis. kand. biol. nauk. Petrozavodsk (in Russian).

Ozerov, A. L. (1988). Nekrobiontnyye dvukrylyye (Diptera) lesov yuga Dalnego Vostoka SSSR [Necrobiotic flies (Diptera) forests south of the Far East of the USSR]. Avtoref. dis. kand. biol. nauk. Moscow (in Russian).

Ozerov, A. L. (1989). K izucheniyu nekrobiontnykh dvukrylykh Dalnego Vostoka SSSR [To the study of necrobiotic flies of far East USSR]. Nasekomyye v ekosistemakh Sibiri i Dalnego Vostoka. Moscow. 110-142 (in Russian).

Pakhomov, A. E. (1998 a). Biogeotsenoticheskaya rol mlekopitayushchikh $\mathrm{v}$ pochvoobrazovatelnykh protsessakh stepnykh lesov Ukrainy [Biogeocenotic role of mammals in the forest steppe soil-forming processes in Ukraine]. Dnepropetrovsk. V. 1 (in Russian).

Pakhomov, A. E. (1998 b). Biogeotsenoticheskaya rol mlekopitayushchikh $\mathrm{v}$ pochvoobrazovatelnykh protsessakh stepnykh lesov Ukrainy [Biogeocenotic role of mammals in the forest steppe soil-forming processes in Ukraine]. Dnepropetrovsk. V. 2 (in Russian).

Pakhomov, O. Ye., Didur, O. O., Kulbachko, Yu. L., Loza, I. M. (2010). Ekokhimichni aspekty isnuvannia bezkhrebetnykh tvaryn u grunti: metody vyvchennia [Ekological and chemical aspects of invertebrate animals existence in soil: methods of study]. Dnipropetrovsk (in Ukrainian).

Payne, J. A. (1965). A summer carrion study on the baby pig Sus scrofa L. Ecology, 46, 592-602.

Stantso, V. V., Chernenko, M. B. (1983). Populyarnaya biblioteka khimicheskikh elementov. Kniga pervaya. Vodorod-Palladiy [Popular library of chemical elements. Book One. HydrogenPalladium.]. Moscow (in Russian).

Tantawi, T. I., El-Kady, E. M., Greenberg, B., El-Ghaffar, H. A. (1996). Arthropod succession on exposed rabbit carrion in Alexandria, Egypt. Journal of Medical Entomology, 33, 566-580. 